\title{
Literary CombiNation: Memory and Space in Contemporary Ukrainian Anthologies
}

\author{
OLENA HALETA \\ I van Franko National University of Lviv, Ukraine \\ olena.haleta@yahoo.com
}

\begin{abstract}
Finding itself at the end of the twentieth century in a situation of post-totalitarianism, post-colonialism and postmodernism, Ukrainian literature faced the problem of finding its own identity. Genres dedicated to the representation of literature, including the increasingly popular genre of anthology, were among the foremost means of creating an image of the literature in its totality. From the end of the 1990s onward, the search for a usable tradition was accompanied by a sense of obligation to highlight one's own modernity, delimit its periods and define its constitutive properties. The national literature has faced the problem taking into account the heritage of totalitarianism and colonialism, which involves coming to terms with its internal space as a multilingual one. On the other hand, the space of literature has extended over the state border, promising to create a new homogeneity of literature and overcoming the differences between domestic and diaspora literature.
\end{abstract}

Key words: anthology, memory, post-colonialism, post-totalitarianism, space, Ukrainian literature.

\section{Three Histories and One Theory}

In the course of the last 20 years Ukrainian literature has been the central character in at least three narratives which have yet to be thoroughly comprehended or described by literary history. During this period Ukrainian literature faced the problem of self-determination in a post-totalitarian, postcolonial, and postmodern situation. After the collapse of the Soviet Union Ukrainian literature found itself in new historical circumstances: it became the literature of an (at least nominally) independent state presented with new opportunities, but burdened with old dependencies. Ukrainian literature inherited the legacy of totalitarianism - the centralised ideological control that had imposed on it the scaffold of socialist realism. Socialist realism, in its turn, dictated not only the content of literature, but its expressive means; it placed all the national literatures of the USSR under the reign of an imperial centre and thrust them into a colonial state.

Colonialism presupposed adopting foreign cultural forms. Any deviation from prescribed patterns was deemed abnormal - a spoiling of borrowed tools. Also compulsory was the acknowledgement of the authority of externally imposed colonial conventions, and any shift from them was considered a violation of pseudouniversal precepts. The inertia resulting from such a condition determined the next stage in literary development: it would be chatacterised by a resolve to deny and negate every vestige 
of postcolonial dependence - until such time as literature was ready to use the heritage of different traditions for its own needs and in a free and unbiased way.

Finally, the collapse of the Soviet system has confronted Ukrainian literature not only with a choice, but a challenge as well. World literature and literary studies have experienced repeated crises related to the end of a modern literary era: the death of the author, the end of the story, the crisis of grand narratives, the crisis of literary history and theory, etc. These circumstances engendered a rethinking of first principles; literature simultaneously needed to reflect on its own identity, and to serve as a potential means of identification for changing cultural communities. The role of literature at the end of the twentieth century has changed drastically due to the increasing role of media and new technologies. Literature has found itself in new circumstances and a new environment, and in order to rethink its situation a completely new discipline was founded - literary anthropology. Its founder, Wolfgang Iser, based his reflections on the generative anthropology of Eric Gans and the semiotic anthropology of Gilbert Ryle. ${ }^{1}$ Iser's approach and the interpretative anthropology of Clifford Geertz claimed literature to be a sphere of pure image creation - the initial activity of fiction and imagination - and a means of human self-broadening. ${ }^{2}$ Hans Ulrich Gumbrecht in his turn has acknowledged the honourable status of literature as 'thinking with risk's - as a medium that, in anthropological rather than social terms, widens the borders of the imaginary. The risk is accepted when a human being not only encounters a new situation, but becomes involved in it and, in response, makes decisions and undergoes change. Literature is able to invent and test new models and mechanisms of selfidentification that stimulate creativity and enable cultural change.

\section{From Literary Anthology to Literary Ontology}

Literary history - a discipline and a genre typically dedicated to the creation of the integral image of a separate literature - has not been a very productive branch of Ukrainian literary studies over the last twenty years. Republications of earlier versions of literary history - those of Mykhailo Hrushevs'kyi, Dmytro Chyzhevs'kyi, Mykhailo Vozniak and even Serhii Iefremov or Mykola Zerov, authoritative in their own time - have enjoyed a certain appeal, but they are scarcely sufficient to the needs of the present. New collectively authored works have appeared or are in progress, including a twelve-volume literary history edited by Vitalii Donchyk at the Institute of Literature of the National Academy of Sciences of Ukraine. Those that are complete, including the History of Ukrainian Literature of the Twentieth Century, winner of the Shevchenko National Prize, despite the value of some sections, have not offered generalizations that are sufficiently convincing. Their structure resembles that of SainteBeuve's Portraits littéraires, and the overview sections are factual in character. Rather than reflecting on criteria for including subject matter, evaluating it and offering generalizations about it, they adhere to the principle of filling in the blank spaces left by Soviet literary historiography or express a utopian desire to encompass everything: Donchyk, for example, declared 'completeness' to be the guiding principle of literary history. ${ }^{4}$

But the problems of literary historiography are hardly limited to post-Soviet methodological disorientation. Western researchers into Ukrainian literature, for their part, have limited their efforts to the analysis of particular literary phenomena or to criticism of the disingenuous universalism of their predecessors or colleagues. They have refrained, at least for now, from extensive historical narratives about literature. On the other hand, another genre representative of the literary process has become increasingly popular in Ukraine: the anthology as a collection of literary works compiled according to the intent and choice of the compiler, not directly dependent on educational needs, and

\footnotetext{
${ }^{1}$ See: W. Iser, Das Fiktive und das Imaginäre: Perspektiven literarischer Anthropologie, Frankfurt am Main,Suhrkamp, 1991 (English Translation: W. Iser, The Fictive and Imaginary: Charting Literary Anthropology, Baltimore: J ohns Hopkins University Press, 1993); W. Iser, Prospecting: From Reader Response to Literary Anthropology, Baltimore, J ohns Hopkins University Press, 1989.

2 See: C. Geertz, 'A Strange Romance: Anthropology and Literature', Profession, 2003, p. 28-36.

3 See: H. U. Gumbrecht, Production of Presence: What Meaning Cannot Convey, Stanford, Stanford University Press, 2004.

${ }^{4}$ V. Donchyk, Nova istoriia ukraïns'koï literatury (teoretyko-metodolohichni aspekty), Kyiv, Feniks, 2005 , p. 16. 
Haleta ANZJ ES 5(2)

designed to reflect separate literary phenomena or literature as a whole, depending on the principle of compilation. The anthologization of Ukrainian literature has accelerated in recent times: whereas in the first 110 years of the literary anthology in Ukraine (1881-1991) there appeared about 60 anthologies in total, in the last twenty years the number was three times greater.

It is worth mentioning that the rise of the anthology as a modern literary and publishing genre is connected to the era of modernism and, even more, to the national modern project. The genre originated in classical times, Meleager's The Wreath (approximately first century BC) generally being regarded as its first example. The rebirth of the genre, and the rise in demand for it, began with the need for building new literary canons based on the principle, not of classical aesthetics, but of historicism, and on the notion of the authenticity and originality of each national literature. The times favoured new nations' quests for identity through the construction of their histories, including literary histories, and through the establishment of corresponding traditions and canons. These were built on the basis of an elitist conception of the modern, encompassing what was thought to be aesthetically the most accomplished and thematically the most significant. According to Gregory J usdanis, an American researcher of Modern Greek literature, 'modernization furthers the formation of national culture to substitute ethnic and religious identity of the stratified system... The literary canon as a collection of texts that tell the nation's history furthers in experiencing unity and gives people an opportunity to see themselves as the citizens of a single nation. ${ }^{5} \mathrm{~J}$ usdanis dwells separately on the role of anthologies in the formation of national and social values, as they help 'define ... what is central, and what is marginal, what has to be reproduced in printing, and what does not.'6

\section{Anthology as a Metagenre}

Scholars have sought to identify the essential features of the literary anthology. William Germans points to its selectivity: 'an anthology aims to present the best of what has been thought and said - and already published. ${ }^{7}$ Anders Olsson agrees with these generally classic criteria and also adds a principle that can be called dual metonymity: 'the anthology is the result of selection; the texts selected are taken out of their original context and brought into the frame of the anthology, that is, the texts are decontextualised to become recontextualised.' ${ }^{\mathrm{J}} \mathrm{J}$ effrey R. Di Leo views an anthology as a 'collection of writings' that can 'announce new and emerging areas of inquiry, [be] illustrative of ideological currents, and help us to organise and understand the past. ${ }^{\prime 9}$ The culture-forming role of collections was pointed out by J ohann Wolfgang Goethe, ${ }^{10}$ Walter Benjamin, ${ }^{11} \mathrm{~J}$ ean Baudrillard, ${ }^{12}$ Mikhail Iampolski ${ }^{13}$ and J ames Clifford. ${ }^{14}$ Krzysztof Pomian has written a history of the arts in Europe as a narrative of changes in the principles of making collections, ${ }^{15}$ while Beata Frydrychak ${ }^{16}$ and

\footnotetext{
${ }^{5}$ G. J usdanis, Belated Modernity and Aesthetic Culture: Inventing National Literature, Minneapolis, University of Minnesota Press, 1991, p. 49.

6 Ibid., p. 66.

${ }^{7}$ W. P. Germano, Getting It Published: A Guide for Scholars and Anyone Else Serious about Serious Books, Chicago: University of Chicago Press, 2008, p. 121.

8 A. Olsson. Managing Diversity: The Anthologization of 'American Literature,' Acta Universitatis Upsaliensis. Studia Anglistica Upsaliensia 111, Uppsala, 2000, p. 15.

9 J. R. Di Leo, 'Analyzing Anthologies' in J . R. Di Leo (ed.), On Anthologies: Politics and Pedagogy, Lincoln, University of Nebraska Press, 2004, p. 3-4.

10 See R. Schellenberg, The Self and Other Things: Goethe the Collector' in Publications of the English Goethe Society, Vol. 81, No. 3, October 2012, pp. 166-177.

11 See O. Haleta, 'Kolektsioner iak kul'turna postat' modernizmu (V. Beniamin i S. Sontag)' in T. Hundorova (ed.), Modernizm pislia postmodernizmu, Kyiv, Foliant, 2008, p. 59-74.

${ }^{12} \mathrm{~J}$. Baudrillard, The System of Objects, London, New York, Verso, 1996 (especially the chapter The Marginal System: Collection').

13 M. Iampolski, Nabliudatel: ocherki istorii videniia, Moskva, Ad Marginem, 2000.

${ }^{14} \mathrm{~J}$. Clifford, The Predicament of Culture: Twentieth-Century Ethnography, Literature, and Art, Cambridge, MA, Harvard University Press, 1988 (especially the chapter 'Collection').

${ }^{15}$ See: K. Pomian, 'Kolekcjonerstwo i filosofia: Narodziny nowożytnego museum' in K. Pomian, Drogi kultury europejskiej: Trzy studia, Warszawa, Polska Akademia Nauk, Instytut Filozofii i Sociologii, 1996, pp. 109-172; K. Pomian, Zbiraczei osobliwości, Warszawa, Państwowy Instytut Wydawniczy, 1996. 
Renata Tańchuk ${ }^{17}$ have researched collecting as a contemporary cultural practice. Researchers in the theoretical orbit of modern literary anthropology and poststructuralism concur that a collection is always a literary and anthropological project, presupposing the restructuring of the original material according to a policy that involves a hierarchy of values and principles of selection, and the definition of the field in question. A literary collection is made according to the rules of a particular game, including rules for making literary judgments.

Finally, as Olsson points out, literary anthologies have an axiological function: 'the result of anthologization, the recontextualised selected text, provides cultural values to the reader.'18 Olsson's notion of cultural value remains vague, the author defining it almost apophatically and by negation. He does, however, stress that a literary collection creates new cultural values that differ from the historical and aesthetic values that the anthologised literary texts originally expressed. Obviously, the newlycreated values are not only different from those articulated in any individual work in the anthology they are qualitatively new, in that they address the (self-) understanding and (self-)identification of a particular society. They do not merely reflect the past; they also are a means for interpreting the present and contemplating the future. The overall sense and message of an anthology is more than the aggregate of the aesthetic quality or historical weight of the works it embraces.

Like much of the literature cited above, this study considers the anthology as a meta-genre or a second-order genre. An anthology in one respect may function as a historical narrative as defined by Frank Rudolf Ankersmit: 'A historical narrative is a historical narrative only insofar as the (metaphorical) meaning of the historical narrative in its totality transcends the (literal) meaning of the sum of its individual statements.' ${ }^{19}$ Like other narratives, it has an author and builds a relationship to a reality, in this instance the reality of literature. Yet an anthology, in contrast to literary history, does not, strictly speaking, narrate - it reflects. Its fabula is of the kind that Gérard Genette called diegetic (in contrast to mimetic). ${ }^{20}$

\section{History and Territory, or 'Our' Literature}

Any fabula presupposes a particular place and time of action. In contrast to literary history, an anthology guided by the principle of cultural memory always begins with the here and now. It does so in response to a pragmatic desire or need, not infrequently on the part of a publisher, to compile some (meta)literary plot that will delimit a significant past and a cultural space, belonging to which will define the borders of our us. Or, as Rüdiger Kunov and Wilfried Raussert put it in their discussion of the role of memory in creating new cultural identities, 'memory speaks of and from a home and the cultural practices which we call 'ours." 21

The building of a significant past includes defining a beginning - not merely a chronological starting point, but an event that semantically establishes a society which thereafter has a special relationship to a particular sample of literary texts. In contrast to the Ukrainian literary histories that had a 'true beginning' (usually the introduction of literacy to the Ukrainian lands), Ukrainian literary anthologies of the nineteenth and early twentieth centuries began with the works of Ivan Kotliarevs'kyi (the 'founder' of the new Ukrainian literature) or, less frequently, Hryhorii Skovoroda or Taras Shevchenko.

\footnotetext{
${ }^{16}$ B. Frydryczak, Świat jako kolekcja: Próba analizy estetycznej natury nowoczesności, Poznań, Wydawnictwo Fundacji Humaniora, 2002.

17 See: R. Tańczuk, Ars colligendi: Kolekcjonowanie jako forma aktywności kulturalnej, Wrocław, Wydawnictwo Uniwersytetu Wrocławskiego, 2011.

18 Olsson, op. cit., p, 15.

${ }^{19}$ F. R. Ankersmit, History and Tropology: The Rise and Fall of Metaphor, Berkeley, University of California Press, 2004, p. 41.

20 G. Genette, Narrative Discourse: An Essay in Method, Ithaca, New York, Cornell University Press, 1980, pp. 27, 280.

${ }^{21}$ R. Kunow and W. Raussert (eds.), Cultural Memory and Multiple Identities, Berlin, Lit, 2008, pp. 9-10. 
Haleta ANZJ ES 5(2)

In this way, the borders - not only linguistic, but also stylistic, aesthetic and ideological - of the national literature's self-identification were set. But already at the beginning of the twentieth century a number of other starting points were selected: the death of Shevchenko (in an anthology compiled by Ivan Franko), ${ }^{22}$ or 1917 as the year of October Revolution, or 1918 as the year of publication of Pavlo Tychyna's Soniachni Klarnety (Clarinets of the Sun). In each of these cases the formation of new literary entity was at stake: modern Ukrainian literature (which would later be replaced by Socialist Realist literature). By the beginning of the 1990s a new generation of readers encountered the problem of choosing their own significant past. The problem was, in part, chronological. The connection to the past had been severed by totalitarianism and the colonial condition; having survived this historical trauma, literature needed to recover its interrupted tradition. On the one hand, anthologies endeavoured to differentiate themselves from their predecessors, mainly by invoking the notion of the generation and doing so decade by decade: there were anthologies of poets of the 1980s, 1990s and 2000s. ${ }^{23}$ The title of the anthology Pozadesiatnyky (Beyond Decades), compiled by Oles' Hordon, ${ }^{24}$ underscored the generality of this frame. Even the fact that many authors did not readily fit into this framework did not diminish the popularity of this principle of classification. In a situation of overall disorientation there emerged numerous anthologies, inclusion in which appeared to depend solely on the criterion of belonging to a particular generation. Young authors whose literary styles were difficult to unify or adequately define, described themselves as 'beginners' and appeared together in anthologies with such titles as 'Young Vine,' Texts', Beginnings, or 'Waiting for the Theatre'). ${ }^{25}$

\section{Fear of Forgetting and the Burden of Memory}

On the other hand, literature strove to overcome past losses - using the mechanisms of memoryarchive and memory-debt - by returning whole genres and styles to literature, and recovering the memory of tragic historical events. This kind of literature was represented by numerous anthologies of works by Ukrainian authors who had died as victims of political persecution, and by political prisoners. ${ }^{26}$ There also appeared anthologies of Baroque literature, ${ }^{27}$ religious lyrics, ${ }^{28}$ intimate lyrics, ${ }^{29}$ and verse by soldiers of the Ukrainian independence struggle in the years after the First World War. ${ }^{30}$

The most recent example of a literary archive, and one that explicitly acknowledges its adherence to the idea of memory debt, is a publication titled Rozipiata muza: Antolohiia ukraïns'kykh poetiv, iaki zahynuly nasylnyts'koiu smertiu (The Crucified Muse: An Anthology of Ukrainian Poets Who Died

\footnotetext{
22 I. Franko (ed.), Akordy: Antolohiia ukraïns'koï liryky po smerti Shevchenka, Lviv, Ukraïns'ko-rus'ka vydavnycha spilka, 1903.

23 I. Rymaruk (ed.), Visimdesiatnyky: Antolohiia novoï ukraïns'koï poeziï, Edmonton, CIUS Press, 1990; V. Makhno (ed.), Deviatdesiatnyky: Avtors'ka antolohiia novoï ukraïns'koï poeziï, Ternopil', Lileia, 1998; B.-O. Horobchuk, O. Romanenko (eds.), Dvi tonny naikrashchoï molodoï poeziï: Antolohiia poeziï dvotysiachnykiv, Kyiv, Mauzer, 2007.

24 O. Hordon (ed.), Pozadesiatnyky: Poetychna antolohiia, Lviv, Prestyzh-inform, 1999; O. Hordon (ed.), Pozadesiatnyky-2: Poetychna antolohiia, Lviv, Prestyzh-inform, 2000.

${ }^{25}$ M. Rozumnyi, S. Rudenko (eds.), Molode vyno: Antolohiia poeziï, Kyiv, Smoloskyp, 1994; A. Kokotiukha (ed.), Teksty: Antolohiia prozy, Kyiv, Smoloskyp, 1995; A. Bondar (ed.), Pochatky: Antolohiia molodoï poeziï, Kyiv, Smoloskyp, 1998; N. Miroshnychenko (ed.), U chekanni teatru: Antolohiia molodoï dramaturhiï, Kyiv, Smoloskyp, 1998.

${ }^{26}$ Iu. Kaplan (ed.), Vidlunnia Babynoho Yaru, Kyiv, Yuh, 2001; I. Hermakivs'kyi (ed.), Dzvony z temnytsi: Mala antolohiia poeziï, Ternopil', Lileia, 2003; H. Iefimova (ed.), Shliakhamy pamiati: Antolohiia poetychnykh tvoriv, prysviachenykh pamiati myttsiv Rozstrilianoho Vidrodzhennia, Odesa, 2011; O. Holub (ed.), Poeziia Iz-za grat, Kyiv, Smoloskyp, 2012. ${ }^{27}$ V. Shevchuk (ed.), Voskresinnia mertvykh: Ukraïns'ka barokova drama, Kyiv, Hramota, 2007; L. Ushkalov (ed.), Barokova poeziia Slobozhanshchyny, Kharkiv, Akta, 2002.

28 Ie. Riazaniv (ed.), Ukraïns'ka dukhovna poeziïa XVII-XX st., Kyiv, Naukova dumka, 1996; L. Rudnytskyi (ed.), Antolohiia poezii, prysviachenykh Iosypu Slipomu, Ivano-Frankivs'k, 1999; T. Salyha (ed.), Slovo Blahovistu: Antolohiia ukraïns'koï relihiinoï liryky, Lviv, Svit, 1999; V. Antofiichuk (ed.), Sviati pochuttia, zakladeni v molytvu: Antolohiia ukraïns'koï literaturnoï molytvy, Bucharest, Mustang, 2004.

29 S. Dziuba, T. Dziuba, O. Solomakha (eds.), Pastukhy kvitiv: Antolohiia intymnoï liryky, Chernihiv, Desnians'ka pravda, 1999; V. Boiko (ed.), Slobozhanska muza: Antolohiia liubovnoï liryky 17-20 St., Kharkiv, Maidan, 2000; S. Vasyliev, O. Koval' (eds.).

30 T. Salyha (ed.), Strilets'ka Holhofa, Lviv, Kameniar, 1992.

75
} 
through Violence), compiled by Iurii Vynnychuk. ${ }^{31}$ This collection contains the biographies and works of about 300 poets who died between 1905 and 1959. In contrast to the 1958 anthology Rozstiliane vidrodzhennia (The Executed Renaissance), edited by Iurii Lavrynenko, Vynnychuk, who makes reference to the earlier collection, ${ }^{32}$ rejects selection on the basis of aesthetic criteria in favour of inclusion of all who fulfil the factual criterion stated in the title. As a result, the anthology represents a potential literature, rather than one that was actually written. This thought can be found at beginning of the foreword: 'If everything was limited just to the Holodomor, our Ukraine would be different.'33 The compiler offers the reader a book that is an indictment for a crime against the nation - the elimination of its potential literature. It would have been appropriate to leave blank pages after the biographies of the authors and examples of their work, which in some instances were not easy to find. The collection acknowledges a debt of memory owed to the authors: it cannot forget what happened to them. It also acknowledges a debt of memory to literature: it cannot forget what never happened.

Searching for a significant past and paying the debt of memory superseded all other organising principles in Ukrainian anthologies of the 1990s. Exceptions included an anthology of ten poets and ten prose writers edited by Viacheslav Medvid'34 and a number of anthologies compiled by Volodymyr Danylenko, who tried not only to cover Ukrainian literature as a whole but to discern within it separate territorial and stylistic groupings - the 'Zhytomyr School', for example. ${ }^{35}$ In general, however, criteria of taste gave way as organising principles to a sense of obligation to the past (titles contain such eloquent metaphors as 'the tree of memory' and 'the call of the past'), ${ }^{36}$ to language ${ }^{37}$ or to the nation. 38

It was, in the main, the historical events and literary phenomena of the twentieth century, some of which were experienced by the compilers themselves, that went through a process of return and rethinking in the anthologies of the 1990s. ${ }^{39}$ Only seldom were other chronological limits set - the second half of the twentieth century, for example. ${ }^{40}$ The tendency of compilers to prioritise the twentieth century and to identify themselves with it can perhaps be explained by a yearning to return to the highest peaks that their literature had scaled, and the deepest tragedies that it had endured, in living memory: to Ukrainian modernism, which arose at the turn of the century and was violently destroyed in the 1930s. None of the events that followed seemed of sufficient importance to serve as a new starting point.

\section{The $20^{\text {th }}$ Century: Finding a Solution}

The first conscious effort in Ukraine to end the modern twentieth century trough the genre of the anthology was Povernennia Demiurhiv (Return of Demiurges), also titled Mala Ukraïns'ka Entsyklopediia Aktual'noï Literatury (Small Ukrainian Encyclopaedia of Contemporary Literature),

\footnotetext{
${ }^{31}$ Iu. Vynnychuk (ed.), Rozipiata muza: Antolohiia ukraïns'kykh poetiv, iaki zahynuly nasyl'nyts'koiu smertiu, Lviv, LA Piramida, 2011.

32 Iu. Lavrinenko, Rozstiliane vidrodzhennia: Antolohiia 1917-1933: Poeziia - proza - drama - esei, Paris, Instytut Literacki, 1958.

33 Iu. Vynnychuk (ed.), op. cit., p. 9.

34 V. Medvid' (ed.), Desiat' ukraïns'kykh poetiv. Desiat' ukraïns'kykh prozaïkiv, Kyiv, Roccard, 1995.

35 V. Danylenko (ed.), Kvity v temnii kimnati: Avtors'ka antolohiia suchasnoï novely, Kyiv, Geneza, 1997; V. Danylenko (ed.), Opudalo: ukraïns'ka prozova satyra, humor, ironiia 80-90-kh rokiv XX st., Kyiv, Geneza, 1997; V. Danylenko (ed.), Vecheria na dvanadtsiat person: Zhytomyrs'ka prozova shkola, Kyiv, Geneza, 1997.

36 V. Shevchuk (ed.), Derevo pamiati, Kyiv, Veselka, 1990, 1992, 1995; I. Luchuk (ed.), Dzvinok z mynuloho, Kyiv, Veselka, 1991.

37 V. Luchuk (ed.), Naidorozhchyi skarb: Slovo pro ridnu movu, Kyiv, Radians'kyi pys'mennyk, 1990; V. Luchuk (ed.), Svoho ne tsuraites': Tvory ukraïns'kykh pys'mennykiv pro ridnu movu: Antolohiia, Ternopil', Bohdan, 2009.

38 V. Kolomiiets' (ed.), Nebo Ukraïny: Poetychna trytomna antolohiia, Kyiv, Ukraïns'kyi pysmennyk, 2001.

39 V. Aheieva (ed.), Ukraïns'ka mala proza XX st., Kyiv, Fakt, 2007; I. Luchuk (ed.), Dyvoovyd: Antolohiia ukraïns'koï poeziï XX st., Kyiv, Bohdan, 2007; B. Shchavurs'kyi (ed.), Chervone i chorne: 100 ukraïns'kykh poetok XX St., Kyiv, Bohdan, 2011; B. Shchavurs'kyi (ed.), Chervone i chorne: 100 ukraïns'kykh poetiv XX st., Kyiv, Bohdan, 2011.

${ }^{40} \mathrm{Iu}$. Kovaliv (ed.), Antolohiia ukraïns'koï poeziï druhoï polovyny XX st., Kyiv, Hranoslov, 2001. 
Haleta ANZJ ES 5(2)

which had a chrestomathic addendum. ${ }^{41}$ The compilers' rhetoric, for all that they defined their stance as postmodern (though they did so in different ways), was much akin to the modern discourse. Their recourse to encyclopaedism was suggestive of the Enlightenment and of the modern era's faith in reason, its confidence in the faculties of perception and its love for classification. They celebrated the supremacy of the individual, proclaimed themselves demiurges and invoked Nietzsche with his cult of the will and ideal of the superman. The project became polyphonic only due to the difference of views of the two compilers. Volodymyr Ieshkiliev, despite complaining about the decadent tendency of modernism, began his text with an epigraph from Verlaine and a reference to Nietzsche. His rejection of looking back in quest of a Golden Age of literature and his fulsome praise of the category of new were unlikely to demolish the foundations of the modern, but such calls were very important in the context of the Ukrainian literature of the 1990s. They were among the consequences of the reconstruction of Ukrainian literature's significant past. Ieshkiliev, interested as he was in strategies for turning the modern artistic situation into a future one, viewed the concepts of the past, present and future not as chronological but as axiological. Ieshkiliev offered faith in memory and returned the theme of power to literature as part of a pledge to create a new totality. This, too, was out of step with postmodern intelligent irony.

But Ieshkiliev's totality was violated in the very foreword of his co-editor, Iurii Andrukhovych. Andrukhovych deployed a great deal of intelligent irony as he rehearsed Ieshkiliev's argument in order to dispute them. Irony is what defines Andrukhovych's strategy: instead of offering answers of his own, he paraphrases the question. (His foreword is preceded, emblematically, by an epigraph that is a question.) Andrukhovych asserts that postmodernism presupposes disillusionment about the exclusivity of novelty as a criterion for determining whether an object is a work of art. For that reason he includes "anthologism" in the list of drawbacks, as well as benefits, of postmodernism.

Thus, Andrukhovych's selection of authors for the chrestomathic addendum, where his principles of arranging his material by time and place are made manifest, is more eloquent of his ideas concerning contemporary literature than his foreword. On the one hand we have the simdesiatnyky (the poets of the 1970s), the visimdesiatnyky (the poets of the 1980s) and the deviatdesiatnyky or devianostyky (the poets of the 1990s), on the other - artistic phenomena defined by their association with Lviv, Kyiv and Stanislaviv.

Vasyl' Gabor defined the chronological border of modernity in a similar way in the anthology Ukraïns'ki literaturni shkoly ta hrupy 60-90-kh rokiv XX st. (Ukrainian Literary Schools and Groups from the 1960s to the 1990s). ${ }^{42}$ Referring to the literary collection of Andrukhovych and Ieshkiliev as the first publication where a similar approach had been tried, Gabor begins his anthology with the Kyiv School of poets, also known as the generation of simdesiatnyky (the poets of the 1970s). (In fact, the Ukrainian shistdesiatnyky [poets of the 1960s], who made it possible to speak of a return of literature to Ukraine after the Executed Renaissance of the 1930s, are not included in any of the anthologies that claim to represent modern Ukrainian literature.) The literature of the 1970s and even the end of the 1960s was anthologised from the perspective of the end of the 1980s and the beginning of the 1990s the formative period of the first post-Soviet generation. Regardless of when the authors represented in Andrukhovych's and Gabor's anthologies were first published, they were all still writing actively in the 1990s.

Gabor's anthology, published in 2009, brought to a conclusion a transformation that had begun at the turn of the millennium. A determination to reject tradition and create a modernity of one's own that differed from that of one's predecessor had been explicitly formulated and introduced in the titles of two publications that appeared in 2001: Antolohiia al'ternatyvnoï ukraïns'koï poeziï zminy epokh: Druha polovyna 80-kh - pochatok 90-kh rokiv (An Anthology of Alternative Ukrainian Poetry of the Change of Epochs: The Second Half of the 1980s and the Beginning of the 1990s) and Dvomovna

\footnotetext{
${ }^{41}$ Iu. Andrukhovych, V. Ieshkiliev (eds.), Povernennia demiurhiv: Mala ukraïns'ka entsyklopediia aktual'noï literatury, Ivano-Frankivs'k, Lileia-NV, 1998.

${ }^{42}$ V. Gabor (ed.), Ukraïns'ki literaturni shkoly ta hrupy 60-90-kh rokiv XX st., Lviv, Piramida, 2009.

77
} 
antolohiia molodoï ukraïns'koï poeziï: Protyznachennia (A Bilingual Anthology of Young Ukrainian Poetry: Countermeanings). ${ }^{43}$ These collections not only offered their readers the names of new poets and new means of poetic expression, but defined their era as commencing in the 1980s, the period with which the first post-Soviet generation associated itself.

The new post-Soviet self-awareness, which had begun as negation of the Soviet past, needed new, immanent, principles of self-identification. The 2000s, however, did not introduce many of them. The most important placed emphasis on women's literature, at first in the twentieth century as a whole or in the second half of it, and later in the literature of the last 20 years, when the number of women authors increased considerably. ${ }^{44}$ Anthologies dedicated to particular literary genres have appeared, ${ }^{45}$ intimate lyrics foremost among them. ${ }^{46}$ The twenty-first century began to shape its own canon of authors and works. ${ }^{47}$

In the early 2010s the basic features of the anthology as a genre have drastically changed. Anthologies dedicated to particular topics have emerged; many owe their existence not to the collection and selection of existing literary works, but to the compilation of works written on demand. Their names themselves - An Anthology of Amoral Works, or Total Football, for example - testify to a new conception of the idea of the literary, which is now seen as tolerating wide variation, accepting accident as a structuring principle, and accommodating ideas that at first might seem wholly marginal. ${ }^{48}$ Projects of this kind do not face the past; on the contrary, they are oriented towards the future, but a very near future - one that begins right now. Nor do they aspire to reconstruct society they create it as accidental and temporary, as based on game rather than memory.

\section{Places of Literature and Literary Places}

The division of literature by spatial rather than temporal criteria counters the legacy of centralism. Apart from Kyiv, Lviv and Stanislaviv, which have already been mentioned, recent anthologies reflect such creative locales as Kharkiv (with its literary grouping Chervona Fira [Red Wagon]), Bakhmach (DAK), Nizhyn (Druzi Eliota [Eliot's Friends]) and Ternopil' (Zakhidnyi Viter [Western Wind]). Thanks to the efforts of Volodymyr Danylenko the Zhytomyr School of prose writers has received prominence. Publishing statistics also reveal a geographical spread: in the last 20 years more than

\footnotetext{
${ }^{43}$ Iu. Pozaiak (ed.), Antolohiia al'ternatyvnoï ukraïns'koï poeziï zminy epokh: Druha polovyna 80-kh - pochatok 90-kh rokiv, Kharkiv, Maidan, 2001; A. Bondar, T. Donii (eds.), Dvomovna antolohiia molodoï ukraïnskoï poeziï:

Protyznachennia, Lviv, Asotsiatsiia ukraïns'kykh pys'mennykiv, 2001.

${ }^{44}$ L. Mishchenko (ed.), Sorok ukraïns'kykh poetes: Antolohiia, Lviv, Vydavnytstvo L'vivs'koho Natsional'noho Universytetu im. I. Franka, 2002; T. Likhtei (ed.), Nizhnist': Antolohiia suchasnoï zhinochoï liryky zakarpattia, Uzhhorod, Mystets'ka liniia, 2002; M. Savka (ed.), My i vona: Antolohiia odynadtsiaty poetok, Lviv, Vydavnytstvo Staroho Leva, 2005; V. Gabor (ed.), Neznaioma: Antolohiia ukraïns'koï zhinochoï prozy ta eseïstyky druhoï pol. XX - poch. XXI st., Lviv, LA Piramida, 2005; M. Shun (ed.), STEP, Lviv, LA Piramida, 2012.

${ }^{45}$ L. Onyshkevych (ed.), Antolohiia modernoï ukraïns'koï dramy, Kyiv, Kanads'kyi Instytut Ukraïns'kykh Studii, 1998; N. Miroshnychenko (ed.), Straik illiuzii: Antolohiia suchasnoï ukraïns'koï dramaturhiï, Kyiv, Osnovy, 2004; Iu. Vynnychuk (ed.), Chort zna shcho, Lviv, LA Piramida, 2004; A. Hlushchak (ed.), Antolohiia ukraïns'koï mors'koï poeziï, Odesa, Maiak, 2004; Iu. Vynnychuk (ed.), Potoibichne: Ukraïns'ka hotychna proza, Lviv, LA Piramida, 2005; D. Fedaka (ed.), Ohnianyi zmii: Ukraïns'ka hotychna proza XIX st., Lviv, LA Piramida, 2006; I. Luchuk (ed.), U suzirï raka: Antolohiia ukraïns'koï palindromiï, Ternopil', Bohdan, 2010.

46100 tysiach sliv pro liubov vkliuchaiuchy vyhuky, Kharkiv, Folio, 2007; B. Shchavurskyi (ed.), Uliubleni virshi pro kokhannia, Ternopil', Bohdan, 2007; I. Luchuk, V. Stakh (eds.), Bila knyha kokhannia: Antolohiia ukraïns'koï erotychnoï poeziï, Ternopil', Bohdan, 2008; I. Luchuk (ed.), Liturhiia kokhannia: Antolohiia ukraïns'koï liubovnoï liryky k. XIX - p. XXI st., Ternopil', Bohdan, 2008; M. Sulyma (ed.), Siaivo biloho tila: Antolohiia ukraïns'koï erotychnoï poeziï, Kyiv, Fakt, 2008; V. Kovrei (ed.), Bereznevi koty: Antolohiia ErotArtFestru, Uzhhorod, Lira, 2010.

${ }^{47}$ S. Zhadan (ed.), Dekameron: 10 ukraïns'kykh prozaiikiv ostannikh 10 rokiv, Kharkiv, KSD, 2010; S. Zhadan (ed.), Metamorfozy: 10 ukraïns'kykh poetiv ostannikh 10 rokiv, Kharki, KSD, 2011.

${ }^{48}$ S. Pantiuk (ed.), Amoralka: Antolohiia amoral'nykh tvoriv, Kharkiv, Folio, 2010; T. Malkovych (ed.), Snovydy: Sny ukraïns'kykh pys'mennykiv, Kyiv, A-ba-ba-ha-la-ma-ha, 2010; S. Zhadan (ed.), Pys'mennyky pro futbol: Literaturna zbirna Ukraïny, Kharkiv, KSM, 2011; S. Zhadan (ed.), Totalnyi futbol, Kyiv, Hrani-T, 2012; L. Demydiuk, S. Korchahina (eds.), Miakush, abo Antolohiia smakovoï poeziï, Kharkiv, Folio, 2012. 
Haleta ANZJ ES 5(2)

50 anthologies have appeared in Kyiv, about 25 in Lviv, 17 in Kharkiv, 16 in Ternopil', five in IvanoFrankiv'sk and almost the same number in Luts'k, Uzhhorod and Kaniv. Several other cities and towns can boast of between one and three anthologies, among which are collections of local authors included by birthright.'

However, more important than places where literature is made or published are cities that have become topoi; these have an established literary face their own. There are only a few of them: Kharkiv, ${ }^{49}$ Lviv, 50 and Ivano-Frankivs'k (Stanislaviv). Inclusion of some authors and works in publications that articulate a connection to these cities is determined not so much by place of birth and dwelling or membership of a particular literary group, as by affinity with an idea or a poetics related to a particular urban topos. Kyiv is not included in this list: although it is the capital of the country and its most important publishing centre, one can barely find any anthologies that could demonstrate the specificity of Kyiv as a separate cultural space.

In 2012 the anthology Solomonova Chervona Zirka (The Red Star of Solomon) was published. ${ }^{51}$ Its title combined of the names of the westernmost and easternmost inhabited localities of Ukraine, reflecting an intention to produce an integrated image of the country through literary representations of space. The book contains twenty-five essays written on demand by different authors about their 'small motherlands' - the twenty-five regions (oblasti) of modern Ukraine. The texts are intended to express the relation of literature to landscape or, more precisely, to place, as the question is not only one of scenery but of the symbolic meanings attached to it. Thus, the twenty-five authors strive to demolish the border between the text about a city or region and the text of that city or region. I would venture to say that the former type of text is a travelogue, while the latter belongs to literature 'proper.' But it is not easy to abolish the power of place (a territory and the history related to it), and the texts generally remain under its dominion. Only Taras Prokhas'ko and Ostap Slyvyns'kyi break through to literature proper, their stories creating new meanings and means of reading space (in the case of Slyvyns'kyi through four elements: earth, wood, rock and concrete). The majority of texts are saturated with objective information on such matters as population size, ethnic groups, the number of educational establishments and the results of censuses. Very often records of various kinds are mentioned: the oldest cinema with two auditoriums, the largest European desert, the longest avenue in Europe, the largest underground church in Europe, the shortest subway in the world, the most ancient instance of the meander ornament, and so on. The anthology shows the process, rather than the result, of searching for a language that could give birth to a literature relating to territory. In the course of this quest Iana Dubynians'ka, for example, promises 'not to repeat anything'52 and tries to speak of things from her own experience, Mykola Leontovych tells stories of his city as stories about his friends, while Anton Sanchenko uses irony to create an intimate relationship between the narrator and the narrative. There are also certain intertextual relations among the stories: some cities serve as reference points for others. For example, Luhans'k, Dnipropetrovs'k, Simferopol' and Poltava are compared to Lviv, Kyiv and Donets'k. Sometimes Kharkiv is also mentioned. Kyiv figures as the capital, and other places are counterposed to it as province to centre. Donets'k and Kharkiv play the role of regional centres. Lviv serves as a kind of template of the city or anti-city and as a point of inner reference for other cities within a large and manifold country; the majority of references to Lviv come from the East, which before the collapse of the Soviet Union had other benchmarks. The most extensive such comparison is made in the first essay of the collection, which is about Ukraine's easternmost regional centre, Luhans'k.

\footnotetext{
49 V. Boiko (ed.), Slobozhans'ka muza, Kharkiv, Maidan, 2000; O. Ushkalov (ed.), Kharkiv Forever: Antolohiia molodoï poeziï, Kharkiv, P. P. Iakubenko, 2004; S. Zhadan (ed.), Hoteli Kharkova: Antolohiia novoï kharkivskoï literatury, Kharkiv, Folio, 2008.

50 V. Gabor (ed.), Dvanadtsiatka: Naimolodsha lvivska literaturna bohema 30-kh rokiv XX st.: Antolohiia urbanistychnoï prozy, Lviv, LA Piramida, 2006; M. Shun, V. Gabor (eds.), LiaLiaK: L'vivska literaturna kryïvka, Lviv, LA Piramida, 2010; M. Savka (ed.), My i vona: Antolohiia odynadtsiaty poetok, Lviv, Vydavnytstvo Staroho Leva, 2005.

51 L. Belei (ed.), Solomonova Chervona Zirka, Kyiv, Tempora, 2011.

52 Ibid., p. 90. 
However, most of the regions described do not correspond to mental maps based on historical, ethnic or any other factors. Authors write about the Luhans'k, Sumy, Kirovohrad, Mykolaïv, Cherkasy, Odesa, Lviv, Volyn', Rivne, and Ivano-Frankivs'k regions - places whose arbitrary administrative borders that were often drawn for ideological reasons. Most of these regions are viewed as contingent formations with historically substantial seams and rifts passing through them. Beneath the modern map the lines of an older one become visible, along with richly associative territorial names (Slobozhanshchyna, Donbas, Tavriia, Volyn, Podillia, Polissia, Halychyna, Bukovyna, Hutsul'shchyna, Boikivshchyna, Opillia or Pokuttia) or names that recall different historical periods (Scythia, the Zaporizhian Sich, the 'Dyke Pole' [Wild Field], Het'manshchyna or the Ukrainian People's Republic). The only essay where not only the past but also the future is projected onto a territory is the last in the collection, Rostyslav Semkiv's Zeleni Perspektyvy (Green Perspectives), his story of Ternopil'shchyna.

Perhaps this book will move not only readers, but also literature, from their place of rest. Yet the anthology arouses a desire to travel to, rather than live in, the places described: many of the essays, while offering a multiperspectival view of their objects and attempting to capture and describe their history and topography from different angles, nonetheless create the sense that living there offers no prospects - that real life (including literary life) occurs elsewhere. (It is not without interest that today more than a half of the authors live in Kyiv.) An essay by the Kyiv author Dmytro Antoniuk about Bukovyna, to take a random example, does not differentiate itself stylistically from the rest, and confirms the fact that in the anthology the character of the writing is independent of the author's personal relationship to the territory described. The general problem of composition remains unsolved: mostly the texts follow one another, plodding along from place to place. The book cannot define its genre and gets stuck somewhere between travelogue and scholarly article. There is no fit between the country described here, and literature.

To some extent this predicament is related to the definition of national literature as a literature written in a single national language. This principle has remained intact throughout the modern period. Only since the beginning of the 2010s have deviations from it been observed. Anthologies containing works in languages other than Ukrainian or, more precisely, in sociolects, have appeared in some parts of Ukraine. On the other hand, there are also publications that combine work in several languages associated with a specific event - an international poetry festival, for example. Unlike bilingual publications that present originals and their translations, such anthologies contain only works in the original and are built on the principle of performativity - involvement in a common action. The place of such action, as well as the language of each text, indicates the nature of such anthologies' involvements in particular cultural spaces, while their multilingualism points beyond the frame of a single national literature.

\section{Literature Without Borders}

On the one hand, Ukrainian literature cannot define its place within its own country. Yet, on the other, it is not constrained by national borders. During the twentieth century the Ukrainian emigration's path from exile to diaspora has been documented by émigré anthologies. ${ }^{53}$ The existence of a diaspora literature as a separate literary phenomenon has contributed to the generally accepted view of the Ukrainian literary process as a two-way movement, or as a phenomenon with a life in two worlds. ${ }^{54}$

\footnotetext{
53 This problem is analysed in detail in my articles: O. Haleta, 'Rozstriliane Vidrodzhennia: vid istoriï metafory do metafory istoriï', Slovo i Chas, No. 8, 2012, pp. 58-65; O. Haleta, 'Anthropos - topos - tropos: antolohiia Koordynaty iak poshuk novoï kul'turnoï identychnosti', Naukovi pratsi: Naukovo-metodychnyi zhurnal (Mykolaïv), Vol. 168, No. 156, 2011 , pp. 34-40.

54 See O. Haleta, 'Dva svity chy novyi prostir ukraïns'koï literatury? Ukraïns'ka emigratsiina literatura u dzerkali antolohii', Spheres of Culture: J ournal of Philological, Historical, Social and Media Communication, Political Science and Cultural Studies (Lublin), Vol 1, 2001, pp. 118-26.
} 
Haleta ANZJ ES 5(2)

A rhetoric of the two- or even three-worldness of Ukrainian literature had developed by the end of the 1990s, following the proliferation of contacts among these worlds. ${ }^{5}$ However, in the twenty-first century new circumstances have brought about further changes in the spatial imagination. Many new immigrants do not consider themselves outcasts in the countries where they settle; they build new types of relationship between their place of birth and place of residence. It is no longer language alone that provides emigrant writers a home in common with their colleagues in the country of their origin. Today Ukrainian emigrant writers continue to respond to Ukrainian publishers and the Ukrainian audience. The new cultural space thus formed requires a new definition - such was the argument behind the publication in 2010 of the collection AZ, dva, try ... dvanadtsiat' - lyst u pliashtsi (One, Two, Three... Twelve - Mail in a Bottle), subtitled Anthology of Authors Abroad. ${ }^{56}$ Compilers and authors worked with the concept of 'abroad', rejecting the notion of emigrant literature. Neither was the term 'diaspora' used in the publication - indeed, recent emigrants often think of themselves as being between motherland and diaspora. Leaving the former does not necessarily mean merging into the latter. The new literary situation in which they find themselves is characterised by dispersal, but also by what could be described as a 'new homogeneity.'

As in the case of The Red Star of Solomon, the compilers of the Anthology of Authors Abroad asked their authors to write essays about cities, thus textualizing geographic spaces outside Ukraine for Ukrainian literature. Lacking a specific history of one's own in a new city, one has to begin from the general - from what has been read in reference books, and what has been learnt. Another approach is to get to know a city through literature, a space that belongs to no-one, and thus to everybody; this is the way in which Vasyl' Makhno gets to know New York. But not every city can boast of its own text, so one has to invent it on the spot, guided by topography and place names. The new landscape is usually compared with the one left behind; it is perceived as a time and space where familiar things have become distorted.

Although the circumstances of the authors differ and most of them are not acquainted with one another, Dana Rudyk, the author of the foreword, continually uses the pronoun 'we' as though speaking for a community with common characteristics. But the bond linking members of such a community can only be a shared relationship to literature in Ukraine, and the nature of this relationship is hard to define: Ukraine for the author abroad may be imagined as maternal, native, 'one's own', domestic, mainland, and much else.

This anthology of expatriate authors reveals a fundamental shift in the relationship between language and space: a person, having once moved, becomes a traveller ready to travel again and again, to engage in an active way of life; according to Makhno, such a person has inherited an 'existential feeling of the manifoldness of the world and its otherness. ${ }^{\prime 57}$ Moving space can scarcely be separated into a here and there; it becomes a whole, and all of it becomes the common field of the one literature.

\section{Post Scriptum}

Finding itself at the end of the twentieth century in a situation of post-totalitarianism, postcolonialism and postmodernism, Ukrainian literature faced the problem of discovering an identity for itself. Genres dedicated to the representation of literature, including the increasingly popular genre of anthology, were among the foremost means of creating such an image of the literature in its totality The literature represented in the anthologies defined a cultural memory spanning a past to which it had an affinity (linguistic, stylistic or philosophical), a significant present and an anticipated future. Because of traumas experienced, but not overcome - traumas understood as the loss of a 'golden age' - the (re)construction of cultural memory followed the pattern of a syncopated temporality, a constant return to the times before the catastrophe' of the first part of the twentieth century. It was a return,

${ }^{55}$ J. Kulyk Keefer, S. Pavlychko (eds.), Two Lands: New Visions, Regina, Coteau Books, 1999; E. Hogan (ed.), From Three Worlds: New Writing From Ukraine, Boston, Zephyr Press, 2000.

${ }^{56}$ M. Shun (ed.), AZ, dva, try ... dvanadtsiat' - lyst u pliashtsi: Antolohiia avtorskoho zarubizhzhia, Lviv, LA Piramida, 2010.

57 Ibid., p. 155.

81 
not so much chronological as stylistic, to the times of the germination and florescence of literary modernism, affinity with which was constitutive of the identity of Ukrainian post-Soviet literature in the 1990s.

From the end of the 1990s onward the search for a usable tradition was accompanied by a sence of obligation in anthologies to highlight one's own modernity, delimit its periods and define its constitutive properties. Finally, at the beginning of the second decade of the twenty-first century the anthology has become a performative genre, built on the principle not of selection, but of the project thus orienting itself towards the immediate future and becoming a space of experimentation for multifarious identities, including marginal ones.

Furthermore, the last twenty years have witnessed the reconstruction of cultural spaces related to the national literature and the construction of new ones; as a result, several centres have taken shape that could justifiably claim the status of literary places. The national literature has faced the problem of taking into account the heritage of totalitarianism and colonialism, which involves coming to terms with its internal space as a multilingual one. On the other hand, the space of literature has extended over the state border, promising to create a new homogeneity of literature and overcoming the differences between the domestic and the diasporic. 